\title{
Endowment Origin, Demographic Effects and Individual Preferences in Contests
}

\author{
Curtis R. Price ${ }^{a}$ and Roman M. Sheremeta ${ }^{b}$ \\ ${ }^{a}$ Department of Economics \& Marketing, College of Business, University of \\ Southern Indiana, 8600 University Blvd., Evansville, IN 47712 \\ ${ }^{\mathrm{b}}$ Argyros School of Business and Economics, Chapman University, \\ One University Drive, Orange, CA 92866, USA
}

March 28, 2012

\begin{abstract}
In modern firms the use of contests as an incentive device is ubiquitous. Nonetheless, recent experimental research shows that in the laboratory subjects routinely make suboptimal decisions in contests even to the extent of making negative returns. The purpose of this study is to investigate if changing how agents are endowed with resources can increase the efficiency in contests. To this end, we conduct a laboratory experiment in which subjects are asked to allot costly resources (bids) in an effort to attain an award (prize). In line with other laboratory studies of contests, our results show that subjects overbid relative to theoretical predictions and incur substantial losses as a result. Making subjects earn their initial resource endowments mitigates the amount of overbidding and thus increases overall efficiency. Overbidding is also linked to gender with women bidding higher than men and having lower average earnings. Other demographic information such as religiosity and individual preferences towards winning and risk also contribute to excessive bidding.
\end{abstract}

JEL Classifications: C72, C91, D61, D72, J16

Keywords: contest, experiments, overbidding, endowment, gender, religiosity

Corresponding author: Roman M. Sheremeta; E-mail: sheremet@,chapman.edu

For helpful discussions and comments, we thank Tim Cason, James Choi, Larry Iannaccone, Will Masters, David Ong, Wafa Orman, Jared Rubin, as well as seminar participants at Purdue University, Chapman University, University of Southern Indiana and participants at the Economic Science Association conference in Tucson. We graciously acknowledge the Vernon Smith Experimental Economics Laboratory at Purdue University for facilitating the collection of the data and the University of Southern Indiana for financial support of this research. Our data and z-Tree codes are available upon request. Any remaining errors are ours. 


\section{Introduction}

The use of contests as an incentive device has garnered much attention by researchers. Certainly, competition as an incentive device often has advantages over other non-competitive incentive schemes (Lazear and Rosen, 1981; Nalebuff and Stiglitz, 1983). Even so, these advantages may be eliminated if the agents in these situations make systematically inefficient choices. Since the original studies of Bull et al. (1987) and Millner and Pratt (1989), a number of laboratory studies have shown that subjects make significantly higher bids than predicted. ${ }^{1}$ In some instances, the magnitude of overbidding is so high that subjects make negative expected payoffs. The fact that agents in these instances make decisions which generate negative payoffs is of paramount concern to the organizations which may employ contests as an incentive device and constitutes a problem of moral hazard which is of interest to management researchers and professionals.

The purpose of this study is to investigate if changing how agents are endowed with resources can mitigate the inefficient use of costly resources in contests. To this end, we conduct a laboratory experiment where subjects either receive a windfall endowment or earn their endowment before participating in a lottery contest in order to win a prize. Furthermore, to analyze the impact of preferences and demographic variables we also conduct a demographic questioner and elicit preferences towards risk and winning.

Our results indicate that when subjects earn their endowments overbidding decreases by around $11-16 \%$. Demographic characteristics, such as gender and religiosity, and individual preferences, such as preferences towards winning and risk, are significant predictors of subjects' bidding behavior in contests. Specifically, we find that subjects who indicate higher utility for

\footnotetext{
${ }^{1}$ For a review of experimental findings on contests see Sheremeta et al. (2012).
} 
winning or higher tolerance for risk make higher bids in contests. Surprisingly, demographic effects are even stronger than treatment effects, with women making $25 \%$ higher bids and more religious subjects making $26 \%$ lower bids. These findings contribute to the existing literature on overbidding and efficient contest design, as well as gender differences in competitive environments, which we discuss in the concluding section.

The rest of the paper is organized as follows: In Section 2 we provide brief literature review. Section 3 details the experimental design and procedures. Section 4 reports the results of the experiment and Section 5 concludes.

\section{Related Literature}

The literature on contests has generally fallen into one of three categories: selection into contests, performance in contests, and efficiency of contests. Our study here focuses mostly on the last category which has received significantly less attention in the recent surge of research on contests.

A number of studies have focused on how people self-select into contests depending on individual preferences and demographic characteristics. This strain of literature has likely been driven by the findings of gender differences in the decision to enter into competitive situations (Niederle and Vesterlund, 2007). In particular, this line of literature has found that when given the choice, women more than men tend to select out of competitive compensation schemes and into schemes which reward individual productive behavior (e.g. piece-rate). ${ }^{2}$ These findings are important because they suggest an explanation for why so few women are represented in high

\footnotetext{
${ }^{2}$ The lone exception is the study by Price (2010) where the author fails to replicate the findings of Niederle and Vesterlund (2008) using the same experimental design.
} 
paying competitive careers. ${ }^{3}$ In addition to gender, Dohmen and Falk (2011) find that when subjects have a choice between a fixed payment and a contest, they are more likely to enter the contest if they are less risk-averse, more productive and more optimistic. Bartling et al. (2009) and Balafoutas et al. (2012) further document that, controlling for beliefs, inequality averse and spiteful subjects are less likely to enter contests. In summary, the findings of the literature indicate that people self-select into contests depending on individual preferences and demographic characteristics.

Studies examining performance in contests are mostly based on three canonical models: a lottery contest of Tullock (1980), a rank-order tournament of Lazear and Rosen (1981) and an all-pay auction of Hillman and Riley (1989). The common finding from studies on lottery contests and all-pay auctions is that subjects routinely overbid (equivalent to over-exerting effort) relatively to theoretical predictions (Davis and Reilly, 1998; Potters et al., 1998; Gneezy and Smorodinsky, 2006; Sheremeta, 2010, 2011; Sheremeta and Zhang, 2010; Price and Sheremeta, 2011). In rank-order tournaments overbidding is not as severe (Schotter and Weigelt, 1992; Orrison et al., 2004; Harbring and Irlenbusch, 2011), but it is still present in some studies (Chen et al., 2011). ${ }^{4}$

As noted earlier, this study is more closely related to the literature on efficiency of contests. Recently, there have been several attempts to reduce overbidding in contests and thus to enhance efficiency. One way to do so is to allow subjects to have an extensive learning experience (Lugovskyy et al., 2010). Another way is to let them make decisions as groups, instead of individuals (Sheremeta and Zhang, 2010). However, even extensive learning and group decision-making do not completely eliminate the overbidding phenomenon. Finally,

\footnotetext{
${ }^{3}$ For a thorough review of the gender and competition literature, see Niederle and Vesterlund (2011).

${ }^{4}$ A possible explanation why the magnitude of overbidding is not as severe in rank-order tournaments is that in these tournaments subjects effort is distorted by a random noise and efforts have a convex cost structure.
} 
Sheremeta (2011) shows that constraining individual budgets (and thus constraining strategy space) can reduce overbidding in contests, but such a mechanism is very unlikely to be effective in the world of competitive capital markets where it is relatively easy to borrow money (D’Avolio, 2002).

Our study examines whether overbidding can be reduced and efficiency can be enhanced when subjects earn their initial resource endowment (as it is usually the case in the real-world settings). The idea that costly decisions may be influenced by the origin and, in particular, the effort by which the endowment is received is attributed to Locke (1978). The idea is clear: subjects who have to work or earn money to make decisions in the experiment may choose to make different decisions than subjects who receive money for free. The experimental evidence suggests that this is indeed in the case. In dictator games, researchers have found that earning the endowment decreases subject's contributions (Cherry et al., 2002; Oxoby and Spraggon, 2006). Earning the endowment has also been shown to have an effect on the risk taking behavior (Thaler and Johnson, 1990) and behavior of subjects in the second-price auction (Jacquemet et al., 2009). In public good games, Muehlbacher and Kirchler (2009) and Harrison (2007) documents that subjects who earn (or use their own) money are less likely to contribute to the public good. ${ }^{5}$ In summary, most of the studies document that subjects who earn their endowments behave more in line with standard Nash equilibrium predictions. The purpose of our experiment is to examine whether the overbidding phenomena can be resolved when subjects earn their initial endowments before participating in lottery contests.

\footnotetext{
${ }^{5}$ In contrast, some researchers do not find any significant effect of the endowment origin on subjects' behavior in public goods and redistribution games (e.g. Clark, 1998, 2002; Rutström and Williams, 2000; Cherry et al., 2005).
} 


\section{Experimental Environment, Design and Procedures}

The experiment is based on the seminal rent-seeking lottery contest of Tullock (1980). We chose to work with this model for several reasons. First, as we already mentioned, the lottery contest of Tullock (1980) is the seminal model of rent-seeking and prior research shows that subjects systematically overbid in these contests resulting in compromised efficiency. Moreover, this overbidding constitutes a moral hazard problem about which managerial technicians are fully aware and, as such, captures a specific facet of the managerial profession which we find attractive. Finally, this particular model provides clear theoretical predictions for which to measure efficiency, while the structure of the contest is easy to understand for subjects in the laboratory.

In a simple lottery contest, there are $n$ risk-neutral players who compete for a prize value of $v$. Each player $i$ makes an irreversible bid $b_{i}$ in order to increase the probability of winning the prize, which is modeled with the lottery contest success function $p_{i}=b_{i} / \sum b_{i}$. The expected payoff for player $i$ is equal to the probability of player $i$ winning, $p_{i}$, times the prize valuation, $v$, minus bid, $b_{i}$, i.e. $E\left(\pi_{i}\right)=p_{i} v-b_{i}$. The unique Nash equilibrium bid is $b^{*}=v(n-1) / n^{2}$ and the equilibrium expected payoff is $E\left(\pi^{*}\right)=v / n^{2}$.

In each treatment of our experiment, there are $n=4$ players competing with each other for the prize of $v=120$ experimental francs. Therefore, the equilibrium bid is $b^{*}=22.5$ and the expected payoff is $E\left(\pi^{*}\right)=7.5$. A key feature of our experiment is that there is no theoretical reason why bidding would be different based upon how the subjects receive their endowments. Therefore, the equilibrium bid is constant across our treatments since it does not depend on how the subjects are endowed (see Table 1). 
In the baseline Gift treatment, subjects received a free endowment as a show up fee of $\$ 20$ to play the lottery contest for 30 periods, 5 of which were randomly selected for payment at the end of the experiment. In the Earn treatment, subjects earned their endowments through a real effort task: adding up sets of five randomly generated two-digit numbers by hand, as quickly as possible. ${ }^{6}$ In the Earn treatment, subjects received $\$ 0.85$ per problem that they correctly answered during a timed ten-minute period. This piece-rate was chosen so that on average the subjects would attain a similar endowment to that of the other two treatments. Finally, in the Yardstick treatment, subjects earned their endowments through the same real effort task, however, this time subjects received a $\$ 20$ if they correctly solved more problems than a predetermined amount in a timed ten-minute period. This predetermined hurdle was set at 2 problems but the subjects were not made aware of this fact. This extremely low hurdle was chosen so that all subjects would earn the $\$ 20$ endowment.

The experiment involved 216 undergraduate subjects from Purdue University. The computerized experimental sessions were conducted in the Vernon Smith Experimental Economics Laboratory using z-Tree (Fischbacher, 2007). We ran 6 sessions of each of the three treatments. In each session, there were a total of 12 subjects and the session proceeded in four parts (or three parts in the Gift treatment). Instructions, available in the Appendix, were given to subjects at the beginning of each part and the experimenter read the instructions aloud.

In the first part, subjects made 15 choices in simple lotteries, similar to Holt and Laury (2002). ${ }^{7}$ This method was used to elicit subjects' risk preferences. In the second part, subjects in

\footnotetext{
${ }^{6}$ This task is commonly used in the experimental literature because it is easy to explain, and there is substantial variability in individual performance that is due partly to skill and partly to effort (Niederle and Vesterlund, 2007; Cason et al., 2010).

${ }^{7}$ Subjects were asked to state whether they preferred safe option A or risky option B. Option A yielded \$1 payoff with certainty, while option B yielded a payoff of either $\$ 3$ or $\$ 0$. The probability of receiving $\$ 3$ or $\$ 0$ varied across all 15 lotteries. The first lottery offered a $0 \%$ chance of winning $\$ 3$ and a $100 \%$ chance of winning $\$ 0$, while the last lottery offered a $70 \%$ chance of winning $\$ 3$ and a $30 \%$ chance of winning $\$ 0$.
} 
Earn and Yardstick treatments earned money through adding up sets of five randomly generated two-digit numbers by hand. In the Gift treatment all subjects automatically were given the $\$ 20$ endowment. After learning how much money they have received, subjects participated in a total of 30 periods of the lottery contest. At the beginning of each period, subjects were randomly regrouped to form a 4-player group. Subjects were then allowed to make bids between 0 and 120 for a prize of 120 francs. After all subjects submitted their bids, the computer chose the winner by implementing a simple lottery rule: the chance of receiving the prize was calculated by the number of francs a subject bids divided by the total number of francs all 4 subjects in the group bid. In the third part of the experiment, similar to Sheremeta (2010), subjects were asked to bid for a prize with a value of zero francs. Subjects were told that they would be informed whether they won the contest or not and that all subjects would have to pay their bids. This procedure was used to measure how important it is for subjects to win when winning is costly and there is no monetary reward for winning.

At the conclusion of the experiment, 1 of the 15 lottery choices subjects made in part one was randomly selected for payment. Subjects were also paid for 5 of the 30 periods in part two and for the 1 decision they made in part three. The five rounds were selected randomly by picking five numbers out of a bingo cage. The earnings were converted into US dollars at the rate of 60 francs to $\$ 1$. Average earnings were $\$ 20.37$ per subject and the experiment lasted for about 60 minutes. 


\section{Results}

\subsection{Overview}

Table 1 summarizes average bids and payoffs. Overall, subjects in all treatments significantly overbid relative to the Nash equilibrium prediction (for all treatments p-value $<$ $0.01){ }^{8}$ As a result of significant overbidding, average payoffs are negative. The persistence of overbidding is also shown in Figure 1, displaying the average bid over all 30 periods of the experiment. Although there is a declining trend, even in the last periods of the experiment subjects continue to substantially overbid relative to the Nash equilibrium prediction. ${ }^{9}$

It is also important to emphasize that bids appear completely inconsistent with play of a symmetric, pure-strategy equilibrium. Figure 2 displays the distribution of bids in all treatments, and indicates that bids are distributed on the entire strategy space from 0 to 120 . The distribution of bids is fairly similar across treatments. Such a high variance in individual bids and significant overbidding are consistent with previous results of lottery contest experiments (Davis and Reilly, 1998; Potters et al., 1998; Sheremeta and Zhang, 2010; Price and Sheremeta, 2011; Sheremeta, 2011).

\subsection{Earned Endowment Effects}

The focus of this study is to determine if the origin of endowment influences the degree of overbidding in contests. Table 1 shows that subjects bid 16\% less in the Yardstick treatment relative to the Gift treatment (36.4 versus 43.2 ). Similarly, subjects bid $11 \%$ less in the Earn

\footnotetext{
${ }^{8} \mathrm{We}$ ran a random effects model on a constant with clustered standard errors at the session level for each treatment. The constant coefficients for each treatment are higher than the predicted theoretical values as in Table 1 (all pvalues $<0.01$ ).

${ }^{9}$ Based on the estimation of a random effects model where the dependent variable is a bid and the independent variables are a constant and a period trend, we find that the period trend is significant in two out of the three treatments ( $p$-value $<0.01$ for Yardstick and Earnings; $p$-value $=0.12$ for Gift).
} 
treatment relative to the Gift treatment (38.6 versus 43.2). It is also clear from Figure 1 that the average bids in the Gift treatment are higher than the average bids in the Yardstick and Earn treatments over most periods of the experiment. Nonetheless, as pointed out in Harrison (2007), we must be careful in looking at only average bids within our treatments in a repeated experiment such as ours.

To formally test the differences in bids across treatments, we use a random effects model with standard errors clustered at session level, where the dependent variable is the bid and the independent variables are treatment dummy-variables and a period trend. ${ }^{10}$ The results of the estimation are reported in Table 2. Specification (1) shows results for a comparison of the Gift treatment to the pooled data of the Earn and Yardstick treatments. Subjects in the Gift treatment bid significantly higher than in the two treatments where they had to earn their money. This difference in bidding behavior seems to be strongest in the Yardstick data (specification 2), where on average after including controls subjects tend to bid 6.80 more francs in the Gift treatment relative to the Yardstick treatment. The difference between the Gift and Earn treatment in specification (3) fails to be significant at a traditional 5 percent level, with a p-value of $0.11 .^{11}$ Lastly, specification (4) indicates that bidding behavior across the Earn and Yardstick treatments is similar.

\subsection{Demographic Effects and Bidding Behavior}

In each experimental section, we elicited information about individual preferences for winning (Sheremeta, 2010) and risk (Holt and Laury, 2002). Also, at the end of the experiment

\footnotetext{
${ }^{10}$ For a robustness check, we also tried to control for potential wealth effects by including correct problem counts. The number of correct problem counts in the Yardstick and Earn treatments is not correlated with bids. Moreover, the estimation results on all other coefficients are virtually the same and are available from the authors upon request.

${ }^{11}$ Restricting our analysis to only the last 15 rounds strengthens our results. In particular, all p-values of treatment effects are significant with $\mathrm{p}$-values $<0.08$.
} 
we conducted a demographic questionnaire. The survey was composed of questions regarding gender, religion, major, classes and age. Table 3 provides a summary statistics of the information that we collected from subjects. Accounting for individual preferences and demographic differences, we find several surprising results. The estimation results of different random effect models, where the dependent variable is the bid and the independent variable are different individual characteristics, are reported in Table 4. In all regressions we cluster the standard errors at the session level, as well as control for treatment effects (by using treatment dummy-variables) and period trend.

The estimation of specification (1) in Table 4 indicates a significant and positive correlation between the bid and the winning variable. The winning variable is measured by the bid for the prize value of 0 (the task that we presented subjects with at the end of thirty periods of bidding for the prize value of 120). ${ }^{12}$ The significant positive correlation between the bid and the winning variable suggests that subjects who value winning more make higher bids in lottery contests. This is consistent with previous findings of Sheremeta (2010) and Price and Sheremeta (2011). One may argue that winning coefficient is capturing confusion instead of a utility of winning. The problem with such an argument is that subjects participated in the contest with prize of 0 after they played other contests for 30 periods. Moreover, in estimation of specification (1) we use the quiz variable, measuring the number of correct quiz answers, to control for confusion. ${ }^{13}$ Although we find that subjects who understand the instructions better

\footnotetext{
${ }^{12}$ Although subjects were explicitly told that they would have to pay their bids, we still find that $28 \%$ of all subjects made positive bids, with an average bid of 9.1 in the Gift treatment, 6.1 in the Yardstick treatment, and 8.3 in the Earn treatment. Moreover, there are no statistically significant differences in bidding between three treatments (all pvalues $>0.40$ ).

${ }^{13}$ This is a measure of how well subjects understand the instructions. Before the actual experiment, subjects completed the quiz on the computer to verify their understanding of the instructions. If a subject's answer was incorrect, the computer provided the correct answer. The experiment started only after all participants had answered all quiz questions.
} 
make lower bids in contests, the significant winning coefficient suggests that winning is a component in a subject's utility.

Another strong predictor of subjects' behavior in contests is risk preferences. The estimation of specification (2) in Table 4 indicates a significant and negative correlation between the bid and the safe variable. The safe variable is measured by the number of safe options that subjects chose in the Holt and Laury (2002) risk elicitation task (for the details see footnote 3 ). ${ }^{14}$ A higher number corresponds to a higher level of risk-aversion. The significant negative correlation between the bid and the safe variable indicates that more risk-averse subjects make lower bids in contests. This finding is consistent both with theoretical predictions of Hillman and Katz (1984) and experimental findings of Sheremeta (2011) and Schmidt et al. (2011). Moreover, controlling for both safe and winning variables, we still find that both are significantly impacting individual bidding behavior (specification 3).

In addition to winning and safe, in specification (4) of Table 4 we include different demographic characteristics summarized in Table $3 .{ }^{15}$ The gender variable is an indicator variable, taking a value of 1 for women and 0 for men. The positive and significant correlation between the bid and the gender implies that women bid more than men. This difference is substantial in magnitude and it is persistent throughout the duration of the experiment (Figure 3). Remarkably, the gender effect is even bigger than the treatment effects (compare Figure 1 and Figure 3), with women making $25 \%$ higher bids than men (45.5 versus 36.3 ). Tis difference also holds across the treatments, with women bidding more than men in all three treatments. The gender difference is even more surprising given that we control for other demographic

\footnotetext{
${ }^{14}$ In the experiment, the vast majority of subjects chose the safe option A when the probability of the high payoff in option B was small, and then crossed over to option B.

${ }^{15}$ In 3 out of 18 sessions, we did not conduct the demographic questionnaire.
} 
characteristics as well as individual preferences. ${ }^{16}$ As a result of significantly higher bids, women receive lower average payoffs from the contest than men (-10.5 versus -8.9$)$.

A significant gender effect is found in studies of mathematical abilities, cognitive thinking, and probability evaluations (Geary, 1996; Kimura and Hampson, 1994; Eckel and Grossman, 2002; Powell and Ansic, 1997). In particular, there is evidence that men apply deeper mathematical reasoning and women are more risk-averse. The latter finding is unlikely to explain our results due to several reasons. First, based on a simple OLS regression with robust standard errors, we do not find a significant difference between risk preferences by men and women subjects $(\mathrm{p}$-value $=0.71)$. However, even if women were more risk-averse it would not explain why they overbid more. The less risk-averse players are expected to bid less (not more) due to theoretical predictions (Hillman and Katz, 1984) as well as experimental findings (Sheremeta, 2011; Schmidt et al., 2011). Mathematical reasoning, on the other hand, may be an important factor that influences men's and women's performance in contests. Unfortunately, we do not have data available to test this conjecture.

More recent research indicates that women tend to shy away from competition. For instance, Niederle and Vesterlund (2007) find that twice as many men as women choose the tournament over the piece-rate. The authors investigate several explanations for this difference including confidence, risk aversion, and feedback aversion; although in the end they attribute most of the impact to disparate preferences between the genders. Our findings provide an additional explanation of why women shy away from competition. Based on our findings,

\footnotetext{
${ }^{16}$ It appears that the winning variable becomes insignificant when we control for demographic differences. Further investigation indicates that this is mainly because of the gender effect. Specifically, we find that women bid twice as much for the prize of 0 than men $(9.75$ versus 4.86$)$. The correlation between the gender and winning variable may be due to women being more sensitive to the context of the experiment and they associated a bid of zero with doing nothing (Croson and Gneezy, 2009). Future research is needed to investigate this result in more detail.
} 
women earn lower payoffs in a tournament-like setting and thus they may rationally choose not to enter the tournament. ${ }^{17}$

Our findings concerning gender in contests are also consistent with research on gender effects in auctions (Ham and Kagel, 2006; Casari et al., 2007; Charness and Levin, 2009; Chen et al., 2009; Ong and Chen, 2012). Ham and Kagel (2006) and Casari et al. (2007), for example, find that women are more susceptible to the winner's curse. Controlling for individual ability and other factors, the authors conjecture that women's overbidding in a common value auction may reflect a relative lack of familiarity with competitive market interactions. Overall, it seems that overbidding by women in auctions is a robust phenomenon (Charness and Levin, 2009; Chen et al., 2009). Although contests are rather different than auctions, it is intriguing to find similar gender effects in both environments.

Finally, the religiosity variable, which measures the importance of religion in daily life, is significant in specification (3) of Table 4. Subjects who consider religion to be a very important part of their daily life make $26 \%$ lower bids in contests than others $(32.5$ versus 41.2$) .{ }^{18}$ As with the gender effect, the religiosity effect (i.e., 26\%) is bigger than the treatment effects (i.e., 11$16 \%)$ and is persistent throughout the duration of the experiment (Figure 4).

There are several reasons which may explain the significant difference in behavior of more religious subjects (Iannaccone, 1998). First, it is usually the case that most religions provoke people to care about and trust others (Tan and Vogel, 2008), as well as to be more prosocial (Ahmed, 2009; Benjamin et al., 2012). ${ }^{19}$ This may produce less competitive behavior in

\footnotetext{
${ }^{17}$ Gneezy et al. (2003) also document that more competitive environments cause a significant increase in efforts for men but not for women.

${ }^{18}$ We asked subjects to answer the question "How important do you consider religion in your daily life?". Subjects then chose one of the following answers: (1) very important, (2) somewhat important, (3) a little important, and (4) not at all important. We code the variable religiosity as 1 if subject's answer was (1) and 0 otherwise.

${ }^{19}$ Several experimental studies (Ahmed, 2009; Benjamin et al., 2012) find that more religious people behave more pro-socially by contributing more to the public good than less religious people.
} 
contests from more religious subjects. ${ }^{20}$ It is also documented in the literature that more religious people are more compassionate towards the disadvantaged (Batson et al., 1993; Regnerus et al., 1998). Therefore, we would expect that when confronted with other subjects in a contest, more religious subjects may yield the competition in favor of their counterparts. ${ }^{21}$ Disregarding the exact reasons why religiosity impacts individual bidding in contests, it is intriguing to know that it plays such an important role in bidding behavior of subjects in our experiment.

\section{Conclusions}

This study investigates whether the amount of overbidding in contests depends on the origin of the endowment and whether demographic differences and differences in preferences can explain bidding behavior of subjects. We find that when subjects earn their endowments overbidding decreases by around 11-16\%. Demographic characteristics, such as gender and religiosity, and individual preferences, such as preferences towards winning and risk, are significant predictors of subjects' bidding behavior in contests. Surprisingly, demographic effects are even stronger than treatment effects, with women making $25 \%$ higher bids and more religious subjects making $26 \%$ lower bids.

Our results contribute to several areas of research. First, our study contributes to the discussion on how to reduce overbidding in contests and enhance efficiency. Our findings indicate that an important contributing factor to overbidding is the fact that subjects receive windfall endowments (house money) before participating in contests. When subjects earn their

\footnotetext{
${ }^{20}$ Mago et al. (2012) and Savikhin and Sheremeta (2012) find that subjects exhibiting more pro-social behavior make lower bids in contests.

${ }^{21}$ Another explanation could be risk aversion, since religious people are usually more risk averse (Hilary and Hui, 2009; Kumar et al., 2011). However, in estimating specification (3) of Table 4, we control for risk preferences. Moreover, based on a simple OLS regression with robust standard errors, we do not find a significant difference between risk preferences by religious and non-religious subjects ( $\mathrm{p}$-value $=0.39$ ).
} 
endowments the overbidding decreases by around $11-16 \%$. Therefore, our results suggest that one way to increase efficiency in contests is simply by making subjects earn their endowments before participating in contests. This is particularly useful information for managers who are tasked with allotting costly resources to departmental units within an organization.

Second, the results of our experiment can partially explain why all contest studies find that subjects' behavior in contests is heterogeneous, with some subjects making very high and some making very low bids. A usual explanation for a high variance in individual bidding behavior is that subjects have heterogeneous preferences towards winning (Sheremeta, 2010) and risk (Sheremeta, 2011; Schmidt et al., 2011). We also find that subjects' preferences towards winning and risk are significant predictors of individual bidding behavior. However, more importantly, we find that demographic differences, such as gender and religiosity, are significant predictors of subjects' behavior in contests. Specifically, we find that women make $25 \%$ higher bids than men and subjects who consider religion to be a very important part of their daily life make more than $26 \%$ lower bids in contests. Remarkably, demographic effects are even bigger than the treatment effects, suggesting that in addition to heterogeneous preferences, a significant part of differences in individual bidding may be attributed to differences in demographic characteristics. This again is very important for the use and allocation of resources to departmental units within an organization. Just as the manager must allocate resources in a circumspect way, the manager must also anticipate how resources are to be used once they have been allocated within an organization. The evidence from this study suggests that an important aspect of this paradigm is to understand the preferences of those who make decisions about the use and allocation of costly resources. 
Lastly, the results pertaining to gender contribute to the growing literature on gender differences (Croson and Gneezy, 2009). Specifically, our results show that in a contest setting women bid significantly more than men. As a result of significantly higher bids, women receive lower average earnings than men. This may affect women's propensity to enter freely into similar contests and contribute to the discussion of gender preferences for competition. ${ }^{22}$ As outlined in Niederle and Vesterlund (2007), the reluctance to commit to a competitive situation may be an important aspect of explaining the gender-wage disparity (Blau and Kahn, 2006) and low representation of women in top-level corporate management (Bertrand and Hallock, 2001).

In addition to the impact this study has on the current set of literature, this study also suggests advances in future research along two important dimensions. First, as noted above, we have investigated the impact of gender in relation to overbidding in contests. This study highlights a new avenue for studying gender differences in competition (e.g., Gneezy et al., 2009). In particular, future work should consider how previous results concerning women's preference to abstain from competition in wages is related to women's overbidding in the context of contests.

Second, this study also ties the contest literature to the discussion on religiosity. There is a growing number of experimental studies examining the impact of religion and religiosity on economic behavior (Hoffmann, 2012). Given that more than 60\% of Americans self-classify as religious (Joas, 2008), it is imperative to investigate how religiosity impacts individual behavior in competitive environments. From the results of our experiment, it appears that religiosity is as important as gender in explaining individual behavior in contests. It occurs to us that

\footnotetext{
${ }^{22}$ The fact that women perform in contests worse than men also suggests that there may be little demand for women in jobs where competition is present in wages. For details of this concern see Price (2012), where the author places subjects in an environment very similar to Niederle and Vesterlund (2007) except that one subject (a manager) chooses a compensation scheme for another (a worker).
} 
investigations of the impact of demographic factors, such as religiosity and gender, on decisions in competitive environments both inside and outside the laboratory are especially fruitful and insightful avenues for future research. 


\section{References}

Ahmed, A.M. (2009). Are religious people more prosocial? A quasi-experimental study with Madrasah pupils in a rural community in India. Journal for the Scientific Study of Religion, 48, 368-374.

Balafoutas, L., Kerschbamer, R., \& Sutter, M. (2012). Distributional Preferences and Competitive Behavior. Journal of Economic Behavior and Organization, forthcoming.

Bartling, B., Fehr, E., Marechal, M.A., \& Schunk, D. (2009). Egalitarianism and Competitiveness. American Economic Review, 99, 93-98.

Batson, C., Schoenrade, P. \& Ventis, W. (1993). Religion and the individual: A SocialPsychological Perspective. New York: Oxford University Press.

Benjamin, D.J., Choi, J.J., \& Fisher, G. (2012). Religious Identity and Economic Behavior. Working Paper.

Bertrand, M., \& Hallock, K.F. (2001). The Gender Gap in Top Corporate Jobs. Industrial and Labor Relations Review, 55(1), 3-21.

Blau, F., \& Kahn, L.M. (2006). The U.S. Gender Pay Gap in the 1990s: Slowing Convergence. Industrial and Labor Relations Review, 60, 45-66.

Bull, C., Schotter, A., \& Weigelt, K., (1987). Tournaments and piece rates: an experimental study. Journal of Political Economy, 95, 1-33.

Casari, M., Ham, J.C., \& Kagel, J.H. (2007). Selection Bias, Demographic Effects, and Ability Effects in Common Value Auction Experiments. American Economic Review, 97, 12781304.

Cason, T.N., Masters, W.A. \& Sheremeta, R.M. (2010). Entry into winner-take-all and proportional-prize contests: An experimental study. Journal of Public Economics, 94, 604611.

Charness, G., \& Levin, D. (2009). The Origins of the Winner's Curse: A Laboratory Study. American Economic Journal - Micro, 1, 207-36.

Chen, H., Ham, S.H., \& Lim, N. (2011). Designing Multiperson Tournaments with Asymmetric Contestants: An Experimental Study. Management Science, 57, 864-883.

Chen, Y., Katuscak, P., \& Ozdenoren, E. (2009). Why Can't a Woman Bid More Like a Man? Working Paper.

Cherry, T.L., Frykblom, P., \& Shogren, J.F., (2002). Hardnose the dictator. American Economic Review, 92, 1218-1221.

Cherry, T.L., Kroll, .S., \& Shogren, J.F. (2005). The impact of endowment heterogeneity and origin on public good contributions: evidence from the lab. Journal of Economic Behavior and Organization, 57, 357-365.

Clark, J. (2002). House money effects in public good experiments. Experimental Economics, 5, $223-231$.

Clark, J., (1998). Fairness in public good provision: an investigation of preferences for equality and proportionality. Canadian Journal of Economics, 31, 708-729.

Croson, R., \& Gneezy U. (2009). Gender Differences in Preferences. Journal of Economic Literature, 45, 448-474.

D’Avolio, G., (2002). The Market for Borrowing Stock. Journal of Financial Economics, 66, 271-306.

Davis, D., \& Reilly, R. (1998). Do many cooks always spoil the stew? An experimental analysis of rent seeking and the role of a strategic buyer. Public Choice, 95, 89-115. 
Dohmen, T., \& Falk, A. (2011). Performance Pay and Multidimensional Sorting: Productivity, Preferences, and Gender. American Economic Review, 101, 556-90.

Eckel, C.C., \& Grossman, P.J. (2002). Sex Differences and Statistical Stereotyping in Attitudes Toward Financial Risk. Evolution and Human Behavior, 23, 281-295.

Fischbacher, U. (2007). z-Tree: Zurich Toolbox for Ready-made Economic experiments. Experimental Economics, 10, 171-178.

Geary, D.C. (1996). Sexual Selection and Sex Differences in Mathematical Abilities. Behavioral and Brain Sciences, 19, 229-284.

Gneezy, U., \& Smorodinsky, R. (2006). All-Pay Auctions - An Experimental Study. Journal of Economic Behavior and Organization, 61, 255-275.

Gneezy, U., Leonard, K.L., \& List, J.A. (2009). Gender differences in competition: Evidence from a matrilineal and patriarchal society, Econometrica, 77, 1637-1644.

Gneezy, U., Niederle, M. \& Rustichini, A. (2003). Performance in Competitive Environments: Gender Differences. Quarterly Journal of Economics, 118, 1049-1074.

Ham, J.C., \& Kagel, J.H. (2006). Gender Effects in Private Value Auctions. Economic Letters, 92, 375-382.

Harbring, C., \& Irlenbusch, B., (2011). Sabotage in Tournaments: Evidence from a Laboratory Experiment. Management Science, 57, 611-627.

Harrison, G. (2007). House money effects in public good experiments: Comment. Experimental Economics, 10, 429-437.

Hilary, G., \& Hui, K.W. (2009). Does Religion Matter in Corporate Decision Making in America? Journal of Financial Economics, 93, 455-473.

Hillman, A. \& Riley, J.G. (1989). Politically contestable rents and transfers. Economics and Politics, 1, 17-40.

Hillman, A.L., \& Katz, E. (1984). Risk-averse rent seekers and the social cost of monopoly power. Economic Journal, 94, 104-110.

Hoffmann, R. (2012). The Experimental Economics of Religion. Journal of Economic Surveys, forthcoming.

Holt, C.A., \& Laury, S.K. (2002). Risk Aversion and Incentive Effects. American Economic Review, 92, 1644-1655.

Iannaccone, L.R. (1998). Introduction to the Economics of Religion. Journal of Economic Literature, 36, 1465-1495.

Jacquemet, N. Joule, R.V., Luchini, S. \& Shogren, J.F. (2009). Earned wealth, engaged bidders? Evidence from a second-price auction. Economics Letters, 105, 36-38.

Joas, H. (2008). The religious situation in the United States. In Religion Monitor 2008 Europe. Bertelsmann Stiftung.

Kimura, D. \& Hampson, E. (1994) Cognitive pattern in men and women is influenced by fluctuations in sex hormones. Current Directions in Psychological Science, 3, 57-61.

Kumar, A., Page, J.K., Spalt, O.G. (2011). Religious Beliefs, Gambling Attitudes, and Financial Market Outcomes. Journal of Financial Economics, 102, 671-708.

Lazear, E.P., \& Rosen, S. (1981). Rank-Order Tournaments as Optimum Labor Contracts. Journal of Political Economy, 89, 841-864.

Locke, E.A. (1978). The ubiquity of the technique of goal setting in theories of and approaches to employee motivation. Academy of Management Review, 1, 594-601.

Lugovskyy, V., Puzzello, D., \& Tucker, S. (2010). An Experimental Investigation of Overdissipation in the All Pay Auction. European Economic Review, 54, 974-997. 
Mago, S.D., Savikhin, A.S., \& Sheremeta, R.M. (2012). Facing Your Opponents: Social Identification and Information Feedback in Contests. ESI Working Paper.

Millner, E.L., \& Pratt, M.D. (1989). An experimental investigation of efficient rent-seeking. Public Choice, 62, 139-151.

Muehlbacher, S., \& Kirchler, E. (2009). Origin of endowments in public good games: The impact of effort on contributions. Journal of Neuroscience, Psychology, and Economics, 2, 59-67.

Müller, W., \& Schotter, A. (2010). Workaholics and Dropouts in Organizations. Journal of the European Economic Association, 8, 717-743.

Nalebuff, B., \& Stiglitz, J. (1983), Prizes and Incentives: Towards a General Theory of Compensation and Competition. The Bell Journal of Economics, 14, 21-43.

Niederle, M., \& Vesterlund, L. (2007). Do Women Shy Away from Competition? Do Men Compete Too Much. Quarterly Journal of Economics, 122, 1067-1101.

Niederle, M., \& Vesterlund, L. (2011). Gender and Competition. Annual Review of Economics, 3, 601-630.

Ong, D., \& Chen, Z. (2012). Tiger Women: An All-Pay Auction Experiment on Gender Signaling of Desire to Win. Working Paper.

Orrison, A., Schotter, A., \& Weigelt, K. (2004). Multiperson Tournaments: An Experimental Examination. Management Science, 50, 268-79.

Oxoby, R.J., \& Spraggon, J. (2008). Mine and yours: Property rights in dictator games. Journal of Economic Behavior and Organization, 65, 703-713.

Potters, J.C., De Vries, C.G., \& Van Linden, F. (1998). An experimental examination of rational rent seeking. European Journal of Political Economy, 14, 783-800.

Powell, M, \& Ansic, D. (1997). Gender differences in risk behavior in financial decisionmaking: An experimental analysis. Journal of Economic Psychology, 18, 605-628.

Price, C.R. (2010). Do Women Shy Away from Competition? Do Men Compete Too Much?: A (Failed) Replication. Working paper

Price, C.R. (2012). Gender, Competition, and Managerial Decisions. Management Science, 58, 114-122.

Price, C.R., \& Sheremeta, R.M. (2011). Endowment Effects in Contests. Economics Letters, 111, 271-219.

Regnerus, M., Smith, C. \& Sikkink, D. (1998). Who gives to the poor? The influence of religious tradition and political location on the personal generosity of Americans toward the poor. Journal for the Scientific Study of Religion, 37, 481-493.

Rutström, E.E., \& Williams, M.B. (2000). Entitlements and fairness: an experimental study of distributive preferences. Journal of Economic Behavior and Organization, 43, 75-89.

Savikhin, A.S., \& Sheremeta, R.M. (2012). Simultaneous Decision-Making in Competitive and Cooperative Games. Economic Inquiry, forthcoming

Schmidt, D., Sheremeta, R.M., Shupp, R., \& Walker, J. (2011). Resource allocation contests: Experimental evidence. Indiana University, Working Paper.

Schotter, A. \& Weigelt, K. (1992). Asymmetric tournaments, equal opportunity laws, and affirmative action: Some experimental results. Quarterly Journal of Economics, 107, 511539.

Sheremeta, R.M. \& Zhang. J. (2010). Can Groups Solve the Problem of Over-Bidding in Contests? Social Choice and Welfare, 35, 175-197. 
Sheremeta, R.M. (2010). Expenditures and Information Disclosure in Two-Stage Political Contests. Journal of Conflict Resolution, 54, 771-798

Sheremeta, R.M. (2010). Experimental Comparison of Multi-Stage and One-Stage Contests. Games and Economic Behavior, 68, 731-747.

Sheremeta, R.M. (2011). Contest Design: An Experimental Investigation. Economic Inquiry, 49, 573-590.

Sheremeta, R.M., Dechenaux, E., \& Kovenock, D. (2012). A Survey of Experimental Findings on Contests, All-Pay Auctions and Tournaments. ESI Working Paper.

Tan, J.H.W., \& Vogel, C. (2008). Religion and trust: An experimental study. Journal of Economic Psychology, 29, 832-848.

Thaler, R., \& Johnson, E. (1990). Gambling with the house money and trying to break even: the effects of prior outcomes on risky choice. Management Science, 36, 643-660.

Tullock, G. (1980). Efficient Rent Seeking. In James M. Buchanan, Robert D. Tollison, Gordon Tullock, (Eds.), Toward a theory of the rent-seeking society. College Station, TX: Texas A\&M University Press, pp. 97-112. 
Table 1: Average Statistics

\begin{tabular}{lccc}
\hline \hline Treatment & $\begin{array}{c}\text { Average } \\
\text { Endowment }\end{array}$ & $\begin{array}{c}\text { Average } \\
\text { Bid }\end{array}$ & $\begin{array}{c}\text { Average } \\
\text { Payoff }\end{array}$ \\
\hline Equilibrium & & 22.5 & 7.5 \\
Gift & $\$ 20.00(0.0)$ & $43.2(0.8)$ & $-13.2(1.1)$ \\
Yardstick & $\$ 20.00(0.0)$ & $36.4(0.7)$ & $-6.4(1.1)$ \\
Earn & $\$ 18.53(0.1)$ & $38.6(0.8)$ & $-8.6(1.1)$ \\
\hline
\end{tabular}

Standard error of the mean in parentheses

Table 2: Comparison of Treatment Effects

\begin{tabular}{|c|c|c|c|c|}
\hline Specification & (1) & (2) & (3) & (4) \\
\hline Dependent variable, bid & $\begin{array}{c}\text { Gift vs. } \\
\text { Yardstick \& Earn } \\
\end{array}$ & $\begin{array}{l}\text { Gift vs. } \\
\text { Yardstick }\end{array}$ & $\begin{array}{l}\text { Gift vs. } \\
\text { Earn }\end{array}$ & $\begin{array}{c}\text { Yardstick vs. } \\
\text { Earn } \\
\end{array}$ \\
\hline $\begin{array}{l}\text { gift } \\
\qquad[1 \text { if Gift }]\end{array}$ & $\begin{array}{l}5.70 * * \\
(2.83)\end{array}$ & $\begin{array}{l}6.80 * * \\
(2.97)\end{array}$ & $\begin{array}{l}4.60 \\
(2.95)\end{array}$ & \\
\hline $\begin{array}{l}\text { yardstick } \\
\qquad[1 \text { if Yardstick] }\end{array}$ & & & & $\begin{array}{l}-2.20 \\
(1.61)\end{array}$ \\
\hline $\begin{array}{l}\text { period } \\
\quad[\text { period trend, } t]\end{array}$ & $\begin{array}{c}-0.30 * * * \\
(0.07)\end{array}$ & $\begin{array}{c}-0.29 * * * \\
(0.09)\end{array}$ & $\begin{array}{c}-0.26 * * * \\
(0.08)\end{array}$ & $\begin{array}{c}-0.36 * * * \\
(0.09)\end{array}$ \\
\hline constant & $\begin{array}{c}42.17 * * * \\
(1.63)\end{array}$ & $\begin{array}{c}40.84 * * * \\
(2.23) \\
\end{array}$ & $\begin{array}{c}42.61 * * * \\
(1.91) \\
\end{array}$ & $\begin{array}{c}44.15 * * * \\
(1.96) \\
\end{array}$ \\
\hline Observations & 6480 & 4320 & 4320 & 4320 \\
\hline
\end{tabular}

Table 3: Summary of Demographic Characteristics and Preferences

\begin{tabular}{llcccc}
\hline \hline Variable & Description & Mean & Std. Dev. & Min & Max \\
\hline winning & bid for the prize of 0 & 7.85 & 22.50 & 0 & 120 \\
quiz & number of correct quiz answers & 7.13 & 1.01 & 2 & 8 \\
safe & number of safe options & 9.35 & 2.47 & 1 & 15 \\
gender & woman or man & 0.35 & 0.48 & 0 & 1 \\
religiosity & religion is very important & 0.19 & 0.39 & 0 & 1 \\
denomination & Christian or other & 0.48 & 0.50 & 0 & 1 \\
major & business or econ major & 0.30 & 0.46 & 0 & 1 \\
class & number of econ classes taken & 3.50 & 4.13 & 0 & 25 \\
age & participant's age & 20.85 & 1.80 & 18 & 33 \\
\hline
\end{tabular}


Table 4: Determinants of Bids

\begin{tabular}{|c|c|c|c|c|}
\hline Specification & (1) & (2) & (3) & (4) \\
\hline \multicolumn{5}{|l|}{ Dependent variable, bid } \\
\hline earn & $-5.59 * *$ & $-6.80 * *$ & $-5.59 * *$ & -5.39 \\
\hline [1 if Earn] & $(2.83)$ & $(2.98)$ & $(2.85)$ & $(3.38)$ \\
\hline yardstick & -3.58 & -4.69 & -3.64 & -2.77 \\
\hline [1 if Yardstick] & $(2.92)$ & $(2.87)$ & $(2.90)$ & (3.10) \\
\hline period & $-0.30 * * *$ & $-0.30 * * *$ & $-0.30 * * *$ & $-0.36 * * *$ \\
\hline [period trend, $t$ ] & $(0.07)$ & $(0.07)$ & $(0.07)$ & $(0.08)$ \\
\hline winning & $0.15^{* *}$ & & $0.14 * *$ & 0.11 \\
\hline [bid for the prize of 0 ] & $(0.07)$ & & $(0.06)$ & $(0.09)$ \\
\hline quiz & $-5.41 * * *$ & & $-5.64 * * *$ & $-4.95 * * *$ \\
\hline [number of correct quiz answers] & $(1.71)$ & & $(1.65)$ & $(1.84)$ \\
\hline safe & & $-2.10 * * *$ & $-2.14 * * *$ & $-1.92 * * *$ \\
\hline [number of safe options] & & $(0.51)$ & $(0.56)$ & $(0.62)$ \\
\hline gender & & & & $7.14 * * *$ \\
\hline [1 if women] & & & & $(2.76)$ \\
\hline religiosity & & & & $-7.90 * * *$ \\
\hline [ 1 if religion is very important] & & & & $(2.84)$ \\
\hline denomination & & & & -3.83 \\
\hline [1 if Christian] & & & & $(2.41)$ \\
\hline major & & & & -1.74 \\
\hline [ 1 if business or econ major] & & & & $(4.18)$ \\
\hline class & & & & -0.28 \\
\hline [number of econ classes taken] & & & & $(0.57)$ \\
\hline & & & & $-1.20 *$ \\
\hline [participant's age] & & & & $(0.68)$ \\
\hline constant & $84.50 * * *$ & $67.49 * * *$ & $106.25 * * *$ & $134.71 * * *$ \\
\hline & $(13.14)$ & $(5.74)$ & $(14.26)$ & $(18.26)$ \\
\hline Observations & 6480 & 6480 & 6480 & 5400 \\
\hline
\end{tabular}




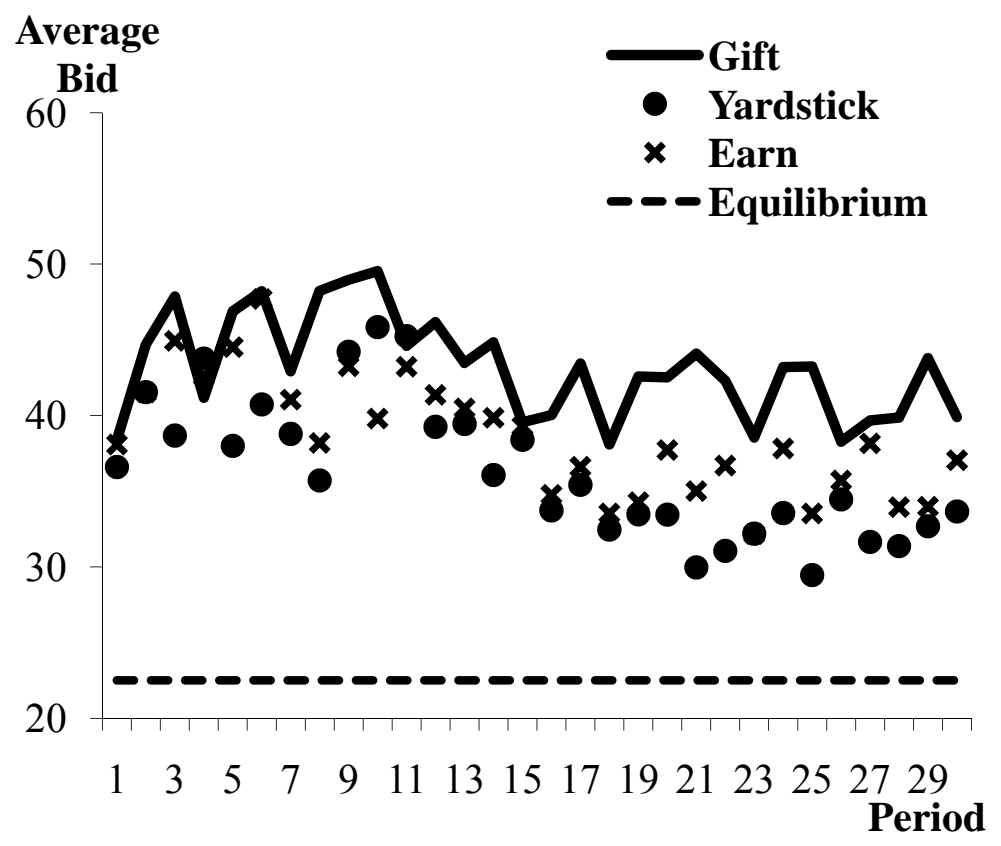

Figure 1: Average Bid Across Periods
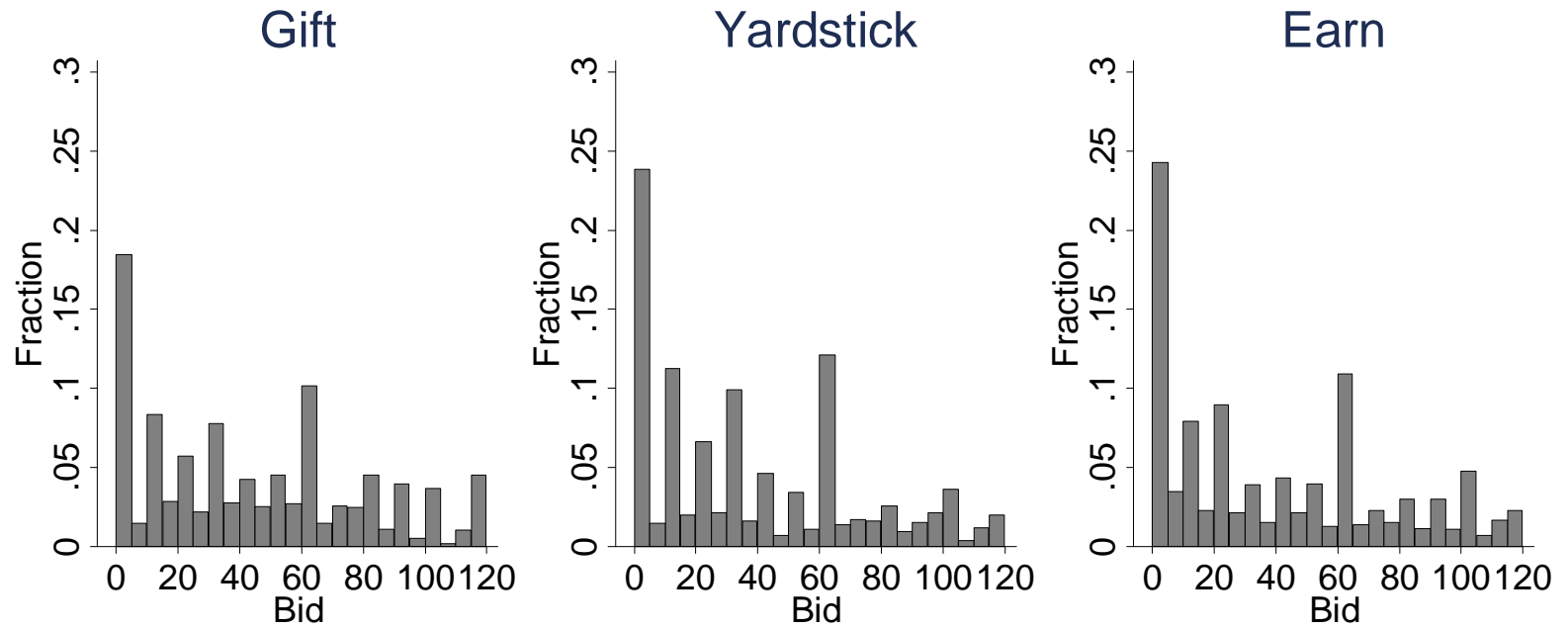

Figure 2: Distribution of Bids in Each Treatment 


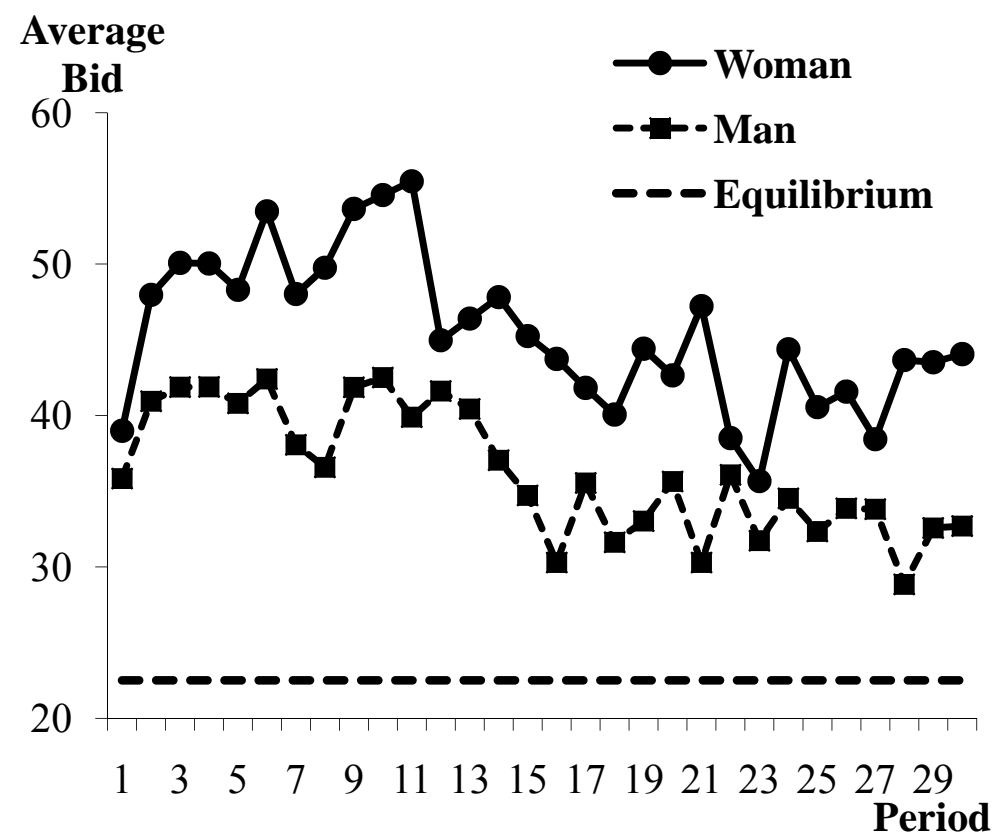

Figure 3: Average Bid by Gender (All Treatments Combined)

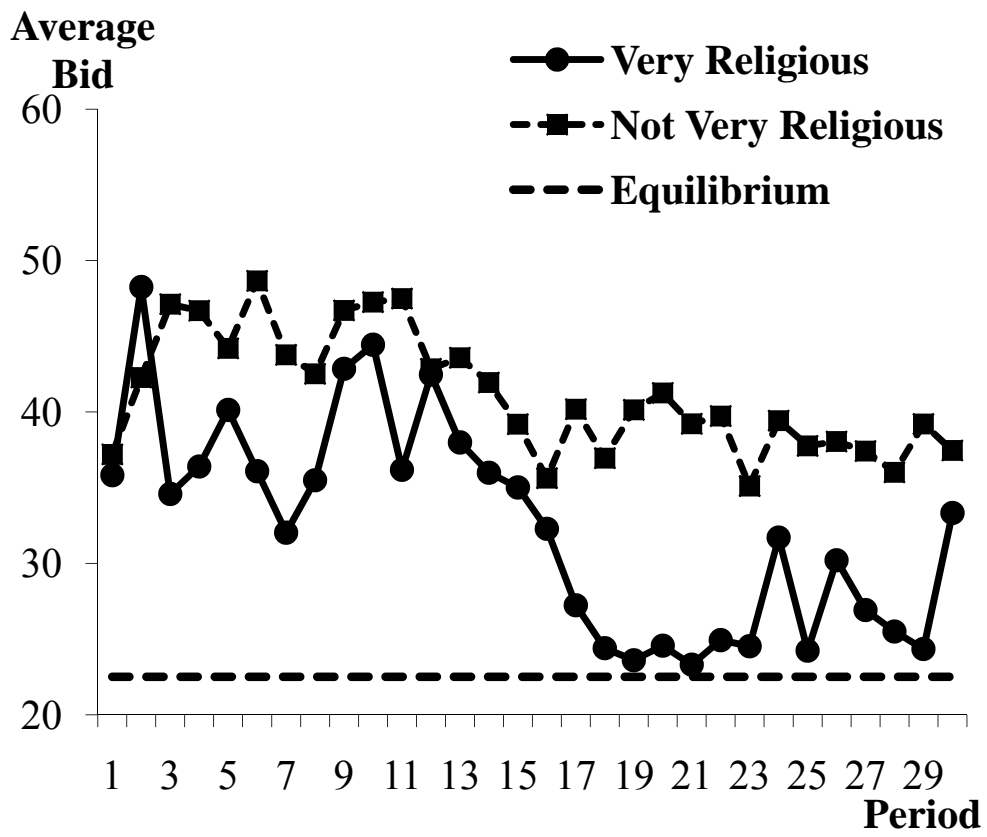

Figure 4: Average Bid by Religiosity (All Treatments Combined) 


\section{Appendix (Not for publication) - Instructions for Treatment Earn}

\section{GENERAL INSTRUCTIONS}

This is an experiment in the economics of strategic decision making. Various research agencies have provided funds for this research. The instructions are simple. If you follow them closely and make appropriate decisions, you can earn an appreciable amount of money.

The experiment will proceed in four parts. The currency used in Part 1 and Part 2 of the experiment is U.S. Dollars. The currency used in Parts 3 and 4 of the experiment is francs. At the end of the experiment, francs will be converted to U.S. Dollars at a rate of $\mathbf{6 0}$ francs to 1 _ dollar. Your earnings today will be calculated as the sum of your earnings in each part of the experiment. At the end of today's experiment, you will be paid in private and in cash. 12 participants are in today's experiment.

It is very important that you remain silent and do not look at other people's work. If you have any questions, or need assistance of any kind, please raise your hand and an experimenter will come to you. If you talk, laugh, exclaim out loud, etc., you will be asked to leave and you will not be paid. We expect and appreciate your cooperation.

At this time we will proceed to Part 1 of the experiment.

\section{INSTRUCTIONS FOR PART 1 YOUR DECISION}

In this part of the experiment you will be asked to make a series of choices in decision problems. How much you receive will depend partly on chance and partly on the choices you make. The decision problems are not designed to test you. What we want to know is what choices you would make in them. The only right answer is what you really would choose.

For each line in the table in the next page, please state whether you prefer option A or option B. Notice that there are a total of $\mathbf{1 5}$ lines in the table but just one line will be randomly selected for payment. You do not know which line will be paid when you make your choices. Hence you should pay attention to the choice you make in every line. After you have completed all your choices a token will be randomly drawn out of a bingo cage containing tokens numbered from 1 to 15. The token number determines which line is going to be paid.

Your earnings for the selected line depend on which option you chose: If you chose option A in that line, you will receive $\mathbf{\$ 1}$. If you chose option B in that line, you will receive either $\mathbf{\$ 3}$ or $\mathbf{\$ 0}$. To determine your earnings in the case you chose option B there will be second random draw. A token will be randomly drawn out of the bingo cage now containing twenty tokens numbered from 1 to 20. The token number is then compared with the numbers in the line selected (see the table). If the token number shows up in the left column you earn $\$ 3$. If the token number shows up in the right column you earn $\$ 0$.

\section{Are there any questions?}

\begin{tabular}{|l||l||l|l||l|}
\hline $\begin{array}{l}\text { Deci } \\
\text { sion } \\
\text { no. }\end{array}$ & $\begin{array}{l}\text { Opti } \\
\text { on } \mathbf{A}\end{array}$ & \multicolumn{2}{|c|}{$\begin{array}{c}\text { Option } \\
\mathbf{B}\end{array}$} & $\begin{array}{c}\text { Please } \\
\text { choose } \\
\text { A or B }\end{array}$ \\
\hline 1 & $\mathbf{\$ 1}$ & $\mathbf{\$ 3}$ never & $\mathbf{\$ 0}$ if $1,2,3,4,5,6,7,8,9,10,11,12,13,14,15,16,17,18,19,20$ & \\
\hline 2 & $\mathbf{\$ 1}$ & $\mathbf{\$ 3}$ if 1 comes out of the bingo cage & $\mathbf{\$ 0}$ if $2,3,4,5,6,7,8,9,10,11,12,13,14,15,16,17,18,19,20$ & \\
\hline 3 & $\mathbf{\$ 1}$ & $\mathbf{\$ 3}$ if 1 or 2 & $\mathbf{\$ 0}$ if $3,4,5,6,7,8,9,10,11,12,13,14,15,16,17,18,19,20$ & \\
\hline 4 & $\mathbf{\$ 1}$ & $\mathbf{\$ 3}$ if $1,2,3$ & $\mathbf{\$ 0}$ if $4,5,6,7,8,9,10,11,12,13,14,15,16,17,18,19,20$ & \\
\hline 5 & $\mathbf{\$ 1}$ & $\mathbf{\$ 3}$ if $1,2,3,4$, & $\mathbf{\$ 0}$ if $5,6,7,8,9,10,11,12,13,14,15,16,17,18,19,20$ & \\
\hline 6 & $\mathbf{\$ 1}$ & $\mathbf{\$ 3}$ if $1,2,3,4,5$ & $\mathbf{\$ 0}$ if $6,7,8,9,10,11,12,13,14,15,16,17,18,19,20$ & \\
\hline 7 & $\mathbf{\$ 1}$ & $\mathbf{\$ 3}$ if $1,2,3,4,5,6$ & $\mathbf{\$ 0}$ if $7,8,9,10,11,12,13,14,15,16,17,18,19,20$ & \\
\hline 8 & $\mathbf{\$ 1}$ & $\mathbf{\$ 3}$ if $1,2,3,4,5,6,7$ & $\mathbf{\$ 0}$ if $8,9,10,11,12,13,14,15,16,17,18,19,20$ & \\
\hline 9 & $\mathbf{\$ 1}$ & $\mathbf{\$ 3}$ if $1,2,3,4,5,6,7,8$ & $\mathbf{\$ 0}$ if $9,10,11,12,13,14,15,16,17,18,19,20$ & \\
\hline 10 & $\mathbf{\$ 1}$ & $\mathbf{\$ 3}$ if $1,2,3,4,5,6,7,8,9$ & $\mathbf{\$ 0}$ if $10,11,12,13,14,15,16,17,18,19,20$ & \\
\hline 11 & $\mathbf{\$ 1}$ & $\mathbf{\$ 3}$ if $1,2,3,4,5,6,7,8,9,10$ & $\mathbf{\$ 0}$ if $11,12,13,14,15,16,17,18,19,20$ & \\
\hline 12 & $\mathbf{\$ 1}$ & $\mathbf{\$ 3}$ if $1,2,3,4,5,6,7,8,9,10,11$ & $\mathbf{\$ 0}$ if $12,13,14,15,16,17,18,19,20$ & \\
\hline 13 & $\mathbf{\$ 1}$ & $\mathbf{\$ 3}$ if $1,2,3,4,5,6,7,8,9,10,11,12$ & $\mathbf{\$ 0}$ if $13,14,15,16,17,18,19,20$ & \\
\hline 14 & $\mathbf{\$ 1}$ & $\mathbf{\$ 3}$ if $1,2,3,4,5,6,7,8,9,10,11,12,13$ & $\mathbf{\$ 0}$ if $14,15,16,17,18,19,20$ & \\
\hline 15 & $\mathbf{\$ 1}$ & $\mathbf{\$ 3}$ if $1,2,3,4,5,6,7,8,9,10,11,12,13,14$ & $\mathbf{\$ 0}$ if $15,16,17,18,19,20$ & \\
\hline
\end{tabular}

\section{INSTRUCTIONS FOR PART 2}


For this part of the experiment you will be asked to calculate the sum of five randomly generated two-digit numbers. You will be given $\mathbf{1 0}$ minutes to calculate the correct sum for a series of these problems. You cannot use a calculator to determine this sum, however you are welcome to use the supplied scratch paper. You submit an answer by clicking the submit button with your mouse. When you enter an answer, the computer will immediately tell you whether your answer is correct or not and supply another summation problem. I will give notice when 30 seconds remain.

\section{YOUR EARNINGS}

You will receive \$1 per problem that you correctly solve within the 10 minutes. Your payment does not decrease if you provide an incorrect answer to a problem.

\section{INSTRUCTIONS FOR PART 3}

\section{YOUR DECISION}

You may have already earned some money from the first part of the experiment, although we will determine how much at the conclusion of the experiment. In addition to this amount, you have also earned some money from the second part of the experiment. In part 3 of the experiment, you may receive either positive or negative earnings.

The third part of the experiment consists of $\mathbf{3 0}$ decision-making periods. At the beginning of each period, you will be randomly and anonymously placed into a group of $\mathbf{4}$ participants. The composition of your group will be changed randomly every period. The reward is worth $\mathbf{1 2 0}$ francs to you and the other three participants in your group. You may bid any integer number of francs between $\mathbf{0}$ and $\mathbf{1 2 0}$ (including 0.5 decimal points). An example of your decision screen is shown below.

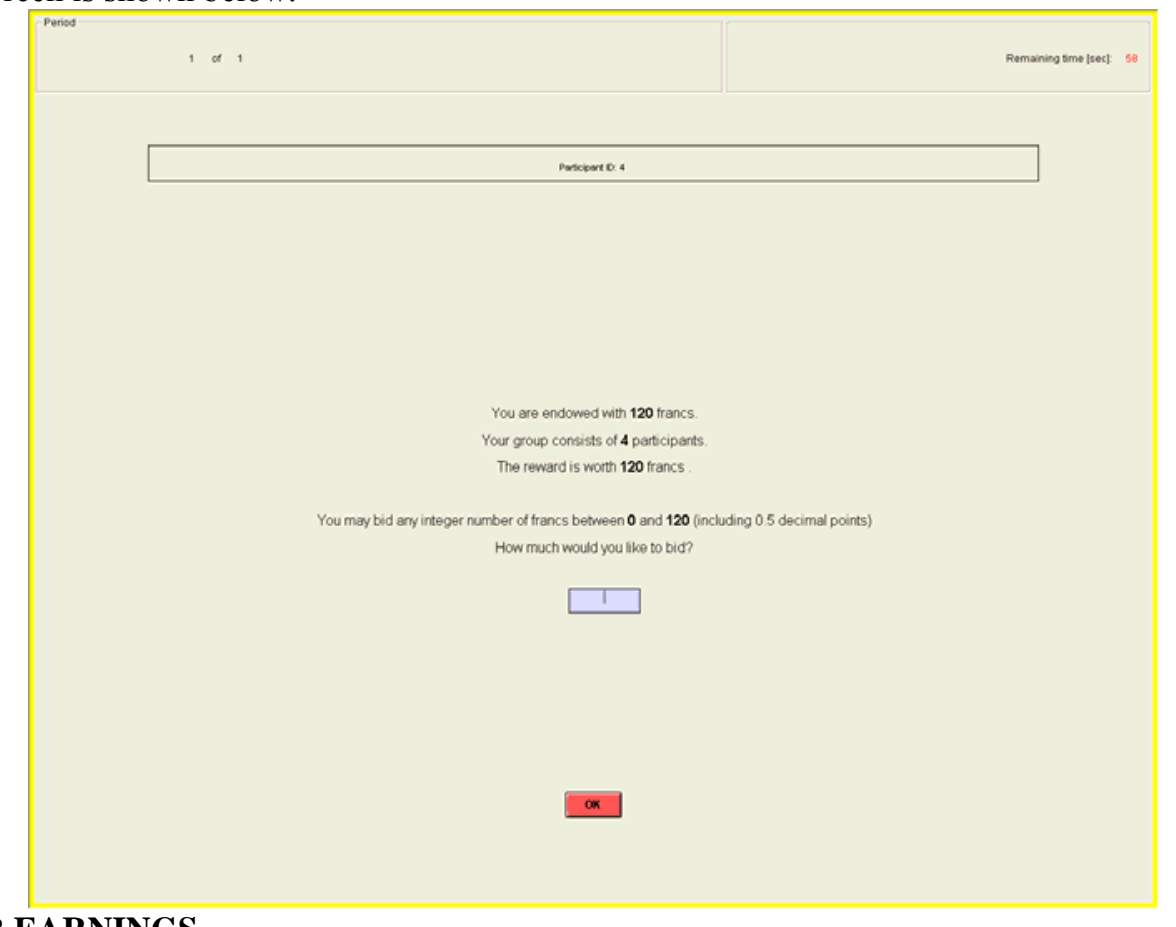

\section{YOUR EARNINGS}

After all participants have made their decisions, your earnings for the period are calculated. Regardless of who receives the reward, all participants will have to pay their bids. Thus, your period earnings will be calculated in the following way:

If you receive the reward: $\quad$ Earnings $=$ Reward - Your Bid $=120-$ Your Bid

If you do not receive the reward: Earnings $=$ No Reward - Your Bid $=0-$ Your Bid

Remember, in the first and second part of this experiment you have earned money. In this part of the experiment, depending on a period, you may receive either positive or negative earnings. At the end of the experiment we will randomly select 5 out of 30 periods for actual payment. You will sum the total earnings for these 5 periods and convert them to a U.S. dollar payment. If the earnings are negative, we will subtract them from your earnings. If the earnings are positive, we will add them to your earnings. 
The more you bid, the more likely you are to receive the reward. The more the other participants in your group bid, the less likely you are to receive the reward. Specifically, for each franc you bid you will receive one lottery ticket. At the end of each period the computer draws randomly one ticket among all the tickets purchased by 4 participants in the group, including you. The owner of the drawn ticket receives the reward of 120 francs. Thus, your chance of receiving the reward is given by the number of francs you bid divided by the total number of francs all 4 participants in your group bid.

Your chance of receiving a reward Your Bid

If all participants bid zero, the reward is randomly assigned to one of the four participants in the group.

\section{Example of the Random Draw}

This is a hypothetical example used to illustrate how the computer makes a random draw. Let's say participant 1 bids 10 francs, participant 2 bids 15 francs, participant 3 bids 0 francs, and participant 4 bids 40 francs. Therefore, the computer assigns 10 lottery tickets to participant 1,15 lottery tickets to participant 2,0 lottery tickets to participant 3 , and 40 lottery tickets for participant 4 . Then the computer randomly draws one lottery ticket out of $\mathbf{6 5}(10+15+0+40)$. As you can see, participant 4 has the highest chance of receiving the reward: $\mathbf{0 . 6 2}=\mathbf{4 0 / 6 5}$. Participant 2 has $0.23=15 / 65$ chance, participant 1 has $\mathbf{0 . 1 5}=\mathbf{1 0} / \mathbf{6 5}$ chance, and participant 3 has $0=\mathbf{0} / \mathbf{6 5}$ chance of receiving the reward.

After all participants make their bids, the computer will make a random draw which will decide who receives the reward. Then the computer will calculate your period earnings based on your bid and whether you received the reward or not.

At the end of each period, your bid, the sum of all bids in your group, whether you received the reward or not, and the earnings for the period are reported on the outcome screen as shown below. Once the outcome screen is displayed you should record your results for the period on your Personal Record Sheet under the appropriate heading.

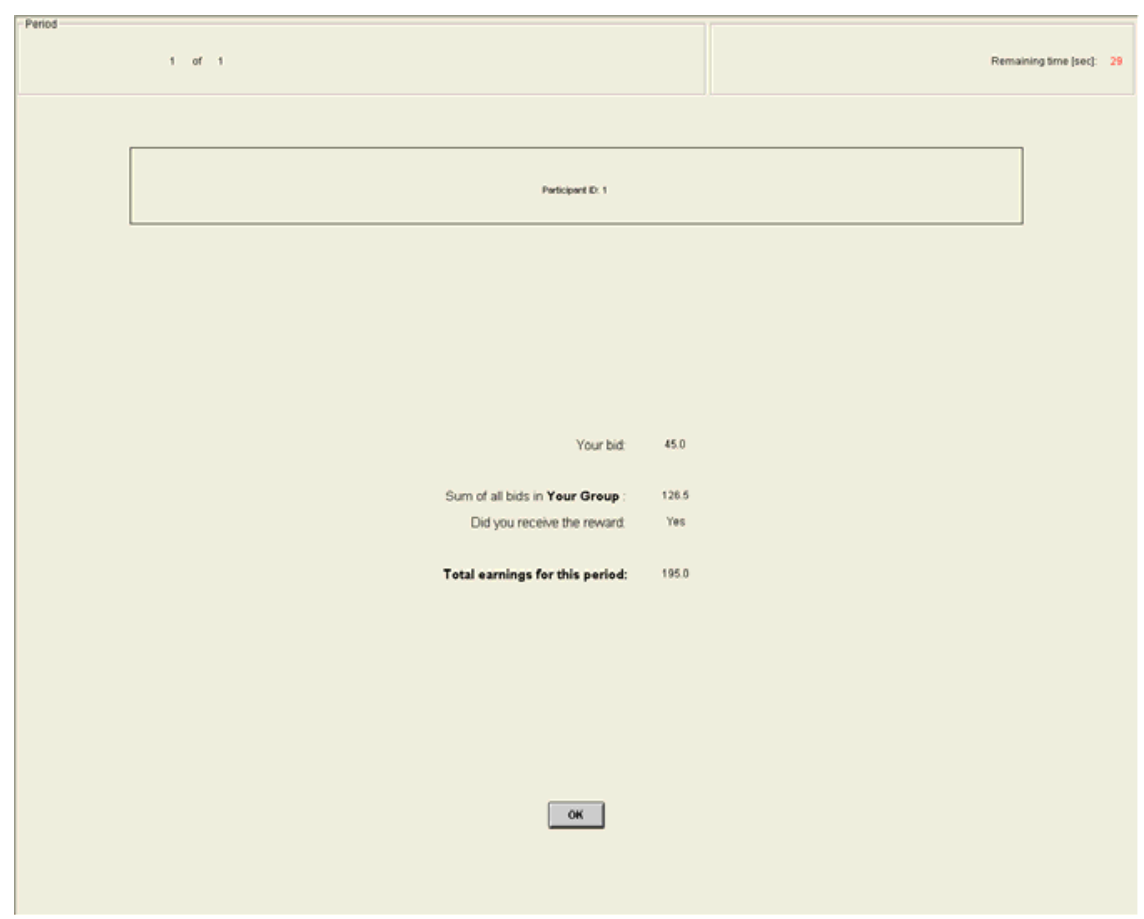

\section{IMPORTANT NOTES}

You will not be told which of the participants in this room are assigned to which group. At the beginning of each period you will be randomly re-grouped with three other participants to from a four-person group. You can never guarantee yourself the reward. However, by increasing your bid, you can increase your chance of receiving the reward. Regardless of who receives the reward, all participants will have to pay their bids.

At the end of the experiment we will randomly choose 5 of the $\mathbf{3 0}$ periods for actual payment in Part 3 using a bingo cage. You will sum the total earnings for these 5 periods and convert them to a U.S. dollar payment.

Are there any questions? 


\section{INSTRUCTIONS FOR PART 4}

The fourth part of the experiment consists of only 1 decision-making period and only one stage. The rules for part 4 are the same as the rules for part 3. At the beginning of the period, you will be randomly and anonymously placed into a group of four participants. You will bid in order to be a winner. The only difference is that in part 4 the winner does not receive the reward. Therefore, the reward is worth $\mathbf{0}$ francs to you and the other three participants in your group. After all participants have made their decisions, your earnings for the period are calculated.

Earnings $=0-$ Your Bid

After all participants have made their decisions, you will learn whether you win or not. The computer then will display your earnings for the period on the outcome screen. Your earnings will be converted to cash and paid at the end of the experiment. 
2012

\section{Economic Science Institute Working Papers}

12-06 Magoa, S. and Sheremeta, R. Multi-Battle Contests: An Experimental Study.

12-05 Sheremeta, R. and Shields, T. Do Liars Believe? Beliefs and Other-Regarding Preferences in Sender-Receiver Games.

12-04 Sheremeta, R., Masters, W. and Cason. T. Winner-Take-All and Proportional-Prize Contests:

Theory and Experimental Results.

12-03 Buchanan, J., Gjerstad, S. and Smith, V. There’s No Place Like Home.

12-02 Corgnet, B. and Rodriguez-Lara, I. Are you a Good Employee or Simply a Good Guy? Influence Costs and Contract Design.

12-01 Kimbrough, E. and Sheremeta, R. Side-Payments and the Costs of Conflict.

\section{1}

11-19 Cason, T., Savikhin, A. and Sheremeta, R. Behavioral Spillovers in Coordination Games.

11-18 Munro, D. and Rassenti, S. Combinatorial Clock Auctions: Price Direction and Performance.

11-17 Schniter, E., Sheremeta, R., and Sznycer, D. Restoring Damaged Trust with Promises, Atonement and Apology.

11-16 Brañas-Garza, P., and Proestakis, A. Self-discrimination: A field experiment on obesity. 11-15 Brañas-Garza, P., Bucheli, M., Paz Espinosa, M., García-Muñoz, T. Moral cleansing and moral licenses: experimental evidence.

11-14 Caginalp, G., Porter, D., and Hao, L. Asset Market Reactions to News: An Experimental Study. 11-13 Porter, D., Rassenti, S. and Smith, V. The Effect of Bidding Information in Ascending Auctions.

11-12 Schniter, E., Sheremeta, R. and Shields, T. Conflicted Minds: Recalibrational Emotions Following Trust-based Interaction.

11-11 Pedro Rey-Biel, P., Sheremeta, R. and Uler, N. (Bad) Luck or (Lack of) Effort?: Comparing Social Sharing Norms between US and Europe. 
11-10 Deck, C., Porter, D., Smith, V. Double Bubbles in Assets Markets with Multiple Generations.

11-09 Kimbrough, E., Sheremeta, R., and Shields, T. Resolving Conflicts by a Random Device.

11-08 Brañas-Garza, P., García-Muñoz, T., and Hernan, R. Cognitive effort in the Beauty Contest Game.

11-07 Grether, D., Porter, D., and Shum, M. Intimidation or Impatience? Jump Bidding in On-line Ascending Automobile Auctions.

11-06 Rietz, T., Schniter, E., Sheremeta, R., and Shields, T. Trust, Reciprocity and Rules.

11-05 Corgnet, B., Hernan-Gonzalez, R., and Rassenti, S. Real Effort, Real Leisure and Real-time Supervision: Incentives and Peer Pressure in Virtual Organizations.

11-04 Corgnet, B. and Hernán-González R. Don’t Ask Me If You Will Not Listen: The Dilemma of Participative Decision Making.

11-03 Rietz, T., Sheremeta, R., Shields, T., Smith, V. Transparency, Efficiency and the Distribution of Economic Welfare in Pass-Through Investment Trust Games.

11-02 Corgnet, B., Kujal, P. and Porter, D. The Effect of Reliability, Content and Timing of Public Announcements on Asset Trading Behavior.

11-01 Corgnet, B., Kujal, P. and Porter, D. Reaction to Public Information in Markets: How Much Does Ambiguity Matter?

2010

10-23 Sheremeta, R. Perfect-Substitutes, Best-Shot, and Weakest-Link Contests between Groups.

10-22 Mago, S., Sheremeta, R., and Yates, A. Best-of-Three Contests: Experimental Evidence.

10-21 Kimbrough, E. and Sheremeta, R. Make Him an Offer He Can't Refuse: Avoiding Conflicts Through Side Payments.

10-20 Savikhim, A. and Sheremeta, R. Visibility of Contributions and Cost of Inflation: An Experiment on Public Goods.

10-19 Sheremeta, R. and Shields, T. Do Investors Trust or Simply Gamble?

10-18 Deck, C. and Sheremeta, R. Fight or Flight? Defending Against Sequential Attacks in the Game of 
Siege.

10-17 Deck, C., Lin, S. and Porter, D. Affecting Policy by Manipulating Prediction Markets:

Experimental Evidence.

10-16 Deck, C. and Kimbrough, E. Can Markets Save Lives? An Experimental Investigation of a Market for Organ Donations.

10-15 Deck, C., Lee, J. and Reyes, J. Personality and the Consistency of Risk Taking Behavior:

Experimental Evidence.

10-14 Deck, C. and Nikiforakis, N. Perfect and Imperfect Real-Time Monitoring in a Minimum-Effort Game.

10-13 Deck, C. and Gu, J. Price Increasing Competition? Experimental Evidence.

10-12 Kovenock, D., Roberson, B.,and Sheremeta, R. The Attack and Defense of Weakest-Link Networks.

10-11 Wilson, B., Jaworski, T., Schurter, K. and Smyth, A. An Experimental Economic History of Whalers' Rules of Capture.

10-10 DeScioli, P. and Wilson, B. Mine and Thine: The Territorial Foundations of Human Property. 10-09 Cason, T., Masters, W. and Sheremeta, R. Entry into Winner-Take-All and Proportional-Prize Contests: An Experimental Study.

10-08 Savikhin, A. and Sheremeta, R. Simultaneous Decision-Making in Competitive and Cooperative Environments.

10-07 Chowdhury, S. and Sheremeta, R. A generalized Tullock contest.

10-06 Chowdhury, S. and Sheremeta, R. The Equivalence of Contests.

10-05 Shields, T. Do Analysts Tell the Truth? Do Shareholders Listen? An Experimental Study of Analysts' Forecasts and Shareholder Reaction.

10-04 Lin, S. and Rassenti, S. Are Under- and Over-reaction the Same Matter? A Price Inertia based Account.

10-03 Lin, S. Gradual Information Diffusion and Asset Price Momentum. 
10-02 Gjerstad, S. and Smith, V. Household expenditure cycles and economic cycles, 1920 - 2010.

10-01 Dickhaut, J., Lin, S., Porter, D. and Smith, V. Durability, Re-trading and Market Performance. 2009

09-11 Hazlett, T., Porter, D., Smith, V. Radio Spectrum and the Disruptive Clarity OF Ronald Coase.

09-10 Sheremeta, R. Expenditures and Information Disclosure in Two-Stage Political Contests.

09-09 Sheremeta, R. and Zhang, J. Can Groups Solve the Problem of Over-Bidding in Contests?

09-08 Sheremeta, R. and Zhang, J. Multi-Level Trust Game with "Insider" Communication.

09-07 Price, C. and Sheremeta, R. Endowment Effects in Contests.

09-06 Cason, T., Savikhin, A. and Sheremeta, R. Cooperation Spillovers in Coordination Games.

09-05 Sheremeta, R. Contest Design: An Experimental Investigation.

09-04 Sheremeta, R. Experimental Comparison of Multi-Stage and One-Stage Contests.

09-03 Smith, A., Skarbek, D., and Wilson, B. Anarchy, Groups, and Conflict: An Experiment on the Emergence of Protective Associations.

09-02 Jaworski, T. and Wilson, B. Go West Young Man: Self-selection and Endogenous Property Rights.

09-01 Gjerstad, S. Housing Market Price Tier Movements in an Expansion and Collapse. 2008

08-09 Dickhaut, J., Houser, D., Aimone, J., Tila, D. and Johnson, C. High Stakes Behavior with Low Payoffs: Inducing Preferences with Holt-Laury Gambles.

08-08 Stecher, J., Shields, T. and Dickhaut, J. Generating Ambiguity in the Laboratory.

08-07 Stecher, J., Lunawat, R., Pronin, K. and Dickhaut, J. Decision Making and Trade without Probabilities.

08-06 Dickhaut, J., Lungu, O., Smith, V., Xin, B. and Rustichini, A. A Neuronal Mechanism of Choice. 08-05 Anctil, R., Dickhaut, J., Johnson, K., and Kanodia, C. Does Information Transparency Decrease Coordination Failure?

08-04 Tila, D. and Porter, D. Group Prediction in Information Markets With and Without Trading 
Information and Price Manipulation Incentives.

08-03 Thomas, C. and Wilson, B. Horizontal Product Differentiation in Auctions and Multilateral Negotiations.

08-02 Oprea, R., Wilson, B. and Zillante, A. War of Attrition: Evidence from a Laboratory Experiment on Market Exit.

08-01 Oprea, R., Porter, D., Hibbert, C., Hanson, R. and Tila, D. Can Manipulators Mislead Prediction Market Observers? 